\title{
HOTEL CRISIS MANAGEMENT FRAMEWORK: MARKETING STRATEGY IN RESPONSE TO COVID-19
}

\author{
Septi Fahmi CHOIRISA \\ Universitas Multimedia Nusantara, Tangerang, Indonesia \\ septi.choirisa@umn.ac.id \\ Ringkar SITUMORANG \\ Universitas Multimedia Nusantara, Tangerang, Indonesia \\ ringkar.situmorang@umn.ac.id
}

\begin{abstract}
The Covid-19 pandemic has struck a crushing blow to the hotel business, with travel restrictions and virus spreading globally, the Hotel Industry altering the pandemic situations in crisis management strategy. This research aims to explore the Hotel Marketing Strategy in Crisis Management during the Covid-19 pandemic. Give insight into how developed countries can deal with a significantly extended crisis and recognize the crucial integrated strategy to survive the pandemic. This study employed a qualitative method with in-depth interviews with 13 hotel managers, both operations and management. Data were collected from the early second quarter to the end of 2020 to investigated the implementation of crisis management strategy. Crisis Management Framework in Hotel Marketing Strategy during the Covid-19 pandemic consists of four stages; the crisis reduction stage, readiness stage, response stage, and recovery stages. Each of the stages has different strategies in order to adjust the uncertain circumstance. Following the four phases of crisis management, this study gives an accurate and current scenario for hotel management to comprehend the construction of a crisis management plan. It also demonstrates the processes of crisis management framework analysis for researchers to undertake further studies in hotel crisis management. Keywords: Hotel Management, Marketing Strategic, Covid-19 pandemic, Crisis Management Framework. DOI: https://doi.org/10.24818/beman/2021.S.I.2-16
\end{abstract}

\section{INTRODUCTION}

At the beginning of 2020, the unpredictable Pandemic Covid-19 had a devastating effect on all aspects of the world. This virus was discovered in Wuhan, China. It was found, in the end, December 2019. The update until April 2020, this virus infected 70 countries. The World Health Organization named the new virus with severe acute respiratory syndrome coronavirus-2 (SARS-Cov-2), and the name of the disease is Corona Virus Disease 2019 (COVID-19). On January 21, 2020, the World Health Organization (WHO) released the first situation report on 2019-nCoV (WHO, 2020a), On 31 January, the WHO update its evaluation of the outbreak as a public health emergency of international concern (WHO, 2020b), and on 
11 March, it declared the outbreak a pandemic (WHO, 2020c). In just two months, the epicentre of the Covid-19 outbreak migrated from China to Italy, Spain, and the United States. Many tourist sites in Asia, where the Chinese are the primary visitors, implemented the crisis management methods for the hotel business on reaction to Covid-10 during the early stages of the pandemic (mid-January to the end of February).

Previous research on crisis management strategies, on the other hand, only looked at a specific point in time (Israeli et al., 2011), and in the aftermath of an epidemic catastrophe, research looked into it (Lee, 2009; Wan, 2013). The tourism industry is an umbrella industry networked with many other sectors in the economy, including hotel, community-level operations, education, financial, agriculture, medical, travel and transportation, construction, real estate, retail, and vice versa (Ranasinghe et al., 2020). The hotel industry's road to recovery has grown much longer as the pandemic has expanded around the globe and crisis management tactics must be altered over time. Various studies have explored about the impact of COVID-19 for the hospitality industry. For example, Sigala (2020) argued that the pandemic of COVID19 will transform the behaviour and experience of tourism stakeholders in hospitality and tourism industry. In the context of developing country, Japutra \& Situmorang (2021) posited the importance of the strategy deployed by hotel industry in facing the challenges and repercussion from the pandemic in Indonesia. Similarly, Alexandra \& Choirisa (2021) investigated the challenges of online education learning in tourism studies during the pandemic COVID-19 in Indonesia. The pandemic of COVID-19 is still around us and continue effecting the tourism industry globally. The exploration of the impact from the crisis is still much to be desired, especially in preparing the condition of the "new normal" for the future.

This study aims to explore how hotel's management responded to the initial and on-going stages of the Covid-19 crisis. Exploring the research gap by conducting ongoing research during the crisis stage to answer what crisis management methods should be implemented for hotel marketing at various points in the Covid-19 pandemic to overcome the unpredictable situation. This study has practical implications by advising the hotel management team to gain a better understanding of the major trends that may emerge as a result of the fundamental and permanent changes that Covid-10 is expected to bring to the industry. Moreover, the discussion may shed light of the Hospitality Industry activation and revitalization in the postpandemic era (Hao et. al. 2020). Also, Governments and hotel sector stakeholders are given recommendations to support them in respond to the situation (Lai and Wong, 2020).

\section{LITERATURE REVIEW}

\subsection{Negative Factors Affecting the Hospitality and Tourism Industry}

The Hospitality and Tourism Industry has been many instances in the past when it has suffered from unexpected or force majeure and suddenly turned down the visitor demand. It is inherently susceptible to the adverse effects of the Hospitality and Tourism industry. Such uncertainties influence tourists' 
intentions to visit a tourism destination and significantly impact travel trends. The large-scale riots in the Gili Islands of Indonesia during the seven months from October 1999 to April 2000 resulted in a substantial decrease of 6,860 tourist arrivals. The estimated total tourism losses of US $\$ 329,280$ to US $\$ 658,560$, compared to those of the same period one year previously (Soemodinoto et al.,2001). The effect of the SARS outbreak on the hospitality and tourism industry in 2002 and 2003 was especially severe in East Asia. The first official SARS case was reported in Guangdong province in the People's Republic of China in November 2002 (Silva, 2003).

\subsection{Crisis Management}

Crisis management is a management practice that deals with non-routine developments and phenomena. These activities are not only concerned with the hectic moments of crisis decision-making but also with the managerial areas of long-range prevention, planning and mitigation management area, the response directly after the crisis, and the sensitive realm of recovery and transition (Enz \& Canina, 2002; Rosenthal, Boin \& Comfort,2001). With simple formulas, each crisis is unique and challenging to resolve, but having such blueprints helps save time, energy, and other resources for a tourist destination in crisis (Sonmez et al., 1999). The aim of developing crisis management is to facilitate the Hospitality and Tourism industry recovery from the negative impact caused by setting the strategy to recovering the economic aspect. Furthermore, Burnett (2002) notes that nearly any crisis should include the seeds of success as roots of failure. The essence of crisis management is cultivating and harvesting that potential success.

Moreover, in Tourism and Hospitality Industry, crisis management is a hot topic. The importance of the link between crisis and tourism has been highlighted in numerous prior studies. According to Sausmarez (2007), the damage generated by a crisis threatens several tourist destinations' national economies and livelihoods. it is essential to watch crisis management tactics to limit the bad consequences. Zang et al. (2005) assessed SARS as a short-term epidemic and investigated the prospects of new developments when the tourism industry recovered. According to McKercher and Chon (2004), the Government should be concerned about the overreaction and lack of coordination, both of which impact long-term tourism development. Despite the fact some study has been done to look at the effects of Covid-19 (Baum et al., 2020), there is still a shortage of research looking into effective crisis management practices in the hotel business. Given the severity of the Covid-19 pandemic, a timely study exploring how hotels perceive and respond to the crisis could provide valuable insight into future pandemic emergencies. Although it is clear that pandemic crises are a critical problem for the hotel sector, most studies were undertaken after, rather than during, an epidemic crisis (Lee, 2009; Wan, 2013).

\section{RESEARCH METHODS}


This study adopted qualitative research to understand the phenomenon in the Hospitality Industry during the Pandemic Covid-19. The characteristics of the qualitative research methodology include small samples and extensive information from each respondent, and a search for meaning, ideas, and relevant issues. Unlike the quantitative research technique, the qualitative research approach involves talking indepth with a few representative individuals to gather detailed information from them (Denzin \& Lincoln, 1994). This research uses the purposive sampling method to select the participants, as this method would offer the best insights for the study (Suri, 2011). As the suitable participant who has appropriate experience and knowledge of the topic, the Hotel Manager was essential for efficient data collection (Gillham, 2005).

\subsection{Sample}

The research sample consists of participants in hotel director, manager, and executive positions. For data collection with in-depth interview forms, a "stratified-purposive sample" was preferred within the qualitative research approach. This strategy aims to get detailed information from volunteers who have been chosen for research (Neuman \& Robson, 2014). Purposive sampling has several advantages, including that it can be utilized in a variety of qualitative research designs (Rai \& Thapa, 2015). Stratified-purposive sampling provides more accurate and detailed information about the sample. In total, 13 of the International and Local chain hotels were interviewed.

\subsection{Data Collection}

The research has a qualitative structure. Since the study was conducted in the Covid-19 pandemic, the in-depth interview was held by virtual meeting through the online application zoom. The interview proceeded from the first quarter to the third quarter of 2020. Each interview lasted approximately 1 (one) hour to 2 (two) hours, which is about 860 minutes from all participants. All the participants answered the research questions so that answers from 13 participants were analyzed. The participants' diverse perspectives were purposely set to provide various points of view and experiences regarding the insight of the Pandemic Covid-19 effect in the Hotel Industry. The main questions discussed during the interviews were how the impact of the COVID-19/crisis had on the hotel's performance.

Following the previous questions, how the Hotel Industry responds to the effect of COVID-19. The last point of the research is how the Hotel Industry team set the strategy during COVID-19 to survive the crisis. Before we conducted the interview session online, we shared the main questions with the participants. Hence, the participants prepared to answer it with the data and enrich the understanding and interpretation (Tracy, 2010). The source was derived from the analysis of both secondary and primary data. Also, the survey with 19 Questions was prepared to investigate the following areas: the impact of Covid-19 on the hotel performance, measures, and actions used during the outbreak and implemented to the extent of formality of the strategic planning systems of the hotels. The results of this study were 
produced through zoom recording (video and sound) and summarizing the contents of word-for-word transcriptions.

\subsection{Data Analysis}

The descriptive analysis technique was used to examine the data. A conceptual structure, data modeling, data organization using tables, and interpretation of findings were all used in the analysis. Separate tables were used to classify responses from three different data collection in the analysis.

\subsection{Demographic characteristics of the participants}

As shown in Table 1, the participants' demographic and departmental features are provided by the coding. The participants are Female and Male between 20 until 40 years old. Approximately $77 \%$ of the participants3-33 in the manager/director/executive position are men, while the ratio of women is around $23 \% .100 \%$ of the participants have a university or higher degree. Subsequently, $69 \%$ of participants work for International Chain hotels and $31 \%$ for a local chain hotel. In addition, $69 \%$ participant who have an experience more than ten years in Hotel Industry.

TABLE 1. THE DEMOGRAPHIC PROFILES

\begin{tabular}{|c|c|c|c|c|c|c|}
\hline Code & Hotel type & Gender & $\begin{array}{c}\text { Age } \\
\text { (Years) }\end{array}$ & Education level & $\begin{array}{c}\text { Experience } \\
\text { in the } \\
\text { tourism } \\
\text { industry } \\
\text { (Years) }\end{array}$ & Position \\
\hline P1 & Local Chain Hotel & Male & $40-45$ & Undergraduate & 20 & Corporate Revenue Director \\
\hline P2 & Local Chain Hotel & Male & $35-40$ & Undergraduate & 14 & Corporate Director of Sales \\
\hline P3 & Local Chain Hotel & Male & $35-40$ & Undergraduate & 15 & General Manager \\
\hline P4 & $\begin{array}{ll}\text { International Chain } \\
\text { Hotel }\end{array}$ & Male & $40-45$ & Undergraduate & 15 & Director of Sales \\
\hline P5 & Local Chain Hotel & Male & $35-40$ & Undergraduate & 12 & Corporate Revenue Director \\
\hline P6 & Local Chain Hotel & Male & $35-40$ & Undergraduate & 14 & Sales Manager \\
\hline P7 & $\begin{array}{ll}\text { International Chain } \\
\text { Hotel }\end{array}$ & Female & $30-35$ & Undergraduate & 10 & Sales Manager \\
\hline P8 & $\begin{array}{l}\text { International Chain } \\
\text { Hotel }\end{array}$ & Female & $30-35$ & Undergraduate & 9 & Senior Sales Manager \\
\hline P9 & Local Chain Hotel & Male & $30-35$ & Undergraduate & 10 & Revenue Manager \\
\hline P10 & Local Chain Hotel & Female & $25-30$ & Undergraduate & 6 & Marcomm Manager \\
\hline P11 & Local Chain Hotel & Male & $30-35$ & Undergraduate & 9 & Event Manager \\
\hline
\end{tabular}


Choirisa, S.F. \& Situmorang, R.

HOTEL CRISIS MANAGEMENT FRAMEWORK: MARKETING STRATEGY IN RESPONSE TO COVID-19

\begin{tabular}{|l|l|l|c|l|c|l|} 
P12 & Local Chain Hotel & Male & $30-35$ & Undergraduate & 12 & Human Resources Manager \\
\hline P13 & $\begin{array}{l}\text { International Chain } \\
\text { Hotel }\end{array}$ & Male & $25-30$ & Undergraduate & & Operations Executive \\
\hline
\end{tabular}

Source: Authors

\section{FINDINGS AND RESULTS}

This study chose a crisis management framework proposed by many scholars after reviewing a variety of hospitality crisis management models (e.g., Cloudman \& Hallahan, 2006; Laws \& Prideaux, 2017; Liu et al., 2015; PATA, 2015; 2003; Pennington-Gray et al., 2011), the four phases of the crisis management process are reduction, readiness, reaction, and recovery.

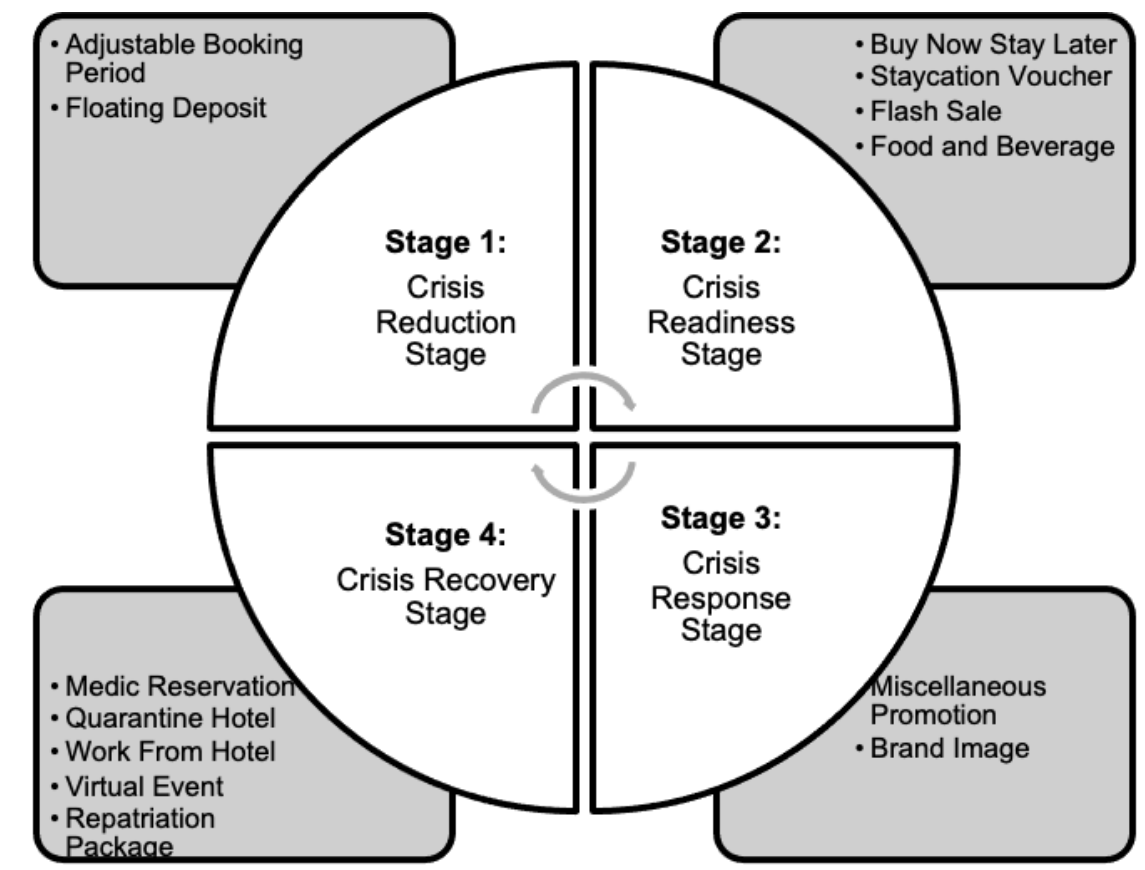

FIGURE 1. FOUR STAGES OF CRISIS MANAGEMENT FRAMEWORK

Source: Cloudman \& Hallahan, 2006; Laws \& Prideaux, 2017; PATA, 2015; 2003; Pennington-Gray et al., 2011

\subsection{The Crisis Reduction Stage}

The finding showed that is the stage of potential catastrophe before it happens. It's a critical time for the hotel to prepare for an impending disaster. However, crises are highly vague and unpredictable, and they might jeopardize an organization's survival. Organizations should concentrate on crisis prevention and planning at this point (Fung et al., 2020). Some hotel managers explained their first experienced dealt with a pandemic, 
"On March 2020, once Indonesian's President announced the outbreak, the hotel occupancy for monthly average about $70-80$ percent and jumped to only single-digit occupancy. It was very devastating. Most of the future booking was cancelled and asked for a refund immediately". (P2

- Corporate Director of Sales)

Most of Interviewee has the similar response in order to express their thought to the pandemic. Several actions were taken to cope with these circumstances. As one of the managers shown his concern as follow,

"We implement the adjustable booking for guests who had a reservation in our hotel even for non-refundable booking. We customize it to adjustable status valid for one year credit to our hotel except for new year eve". (P1 - Corporate Revenue Director).

Another Hotel Director explained the cancellation regulations had been changed since corporate instruction due to force majeure issue,

"For any reservation that has been guaranteed, we follow the corporate office obligation to allow the cancellation, especially for international guests, without any penalty. So that, we waived all the reservation who requested to cancel". (P9 - Revenue Manager).

The concern is not only imposed for rooms but also the banquet. Meeting, Incentive, Conference, and Exhibition (MICE) at the hotel rapidly went down. Some events have been canceled even though it is guaranteed. Following that, the floating deposit was applied,

"For Guaranteed Event, we impose the floating deposit for one-year validation, and also we could convert it to a voucher that could be used in our hotel either for rooms or food and beverages." (P11 - Event Manager).

\subsection{The Crisis Readiness Stage}

The finding highlighted that this level denotes the crisis is affecting the organization. Therefore, contingency plans will be prepared as a primary goal to protect employees, visitors, and property (Liu et al., 2015; Tew et al., 2008). The organization should determine the severity and type of damage that has occurred in the hotel (Novelli et al., 2018). At this stage, the hotel recognizes the circumstances and develop their strategy to survive in uncertainty conditions. Some participants describe the method applied in a way to escalate their hotel revenue. Some of the hotel managers have described the new strategy applied,

"We create the promotion - buy now stay later - with the lowest rate for a certain booking period. This strategy will boost the basic occupancy. For instance, our normal rate was Rp. 2.500 .000 includes breakfast, but now we offer Rp. 500.000,- with minimum stay for 2 (two) nights includes 
breakfast. Surprisingly the market responded quickly until our reservation team has a non-stop booking". (P8 - Senior Sales Manager).

This strategy also applied for the other hotel,

"At first, we have self-quarantine with 14 nights, 21 nights, and 1-month package eventually this strategy is not working since the conditions were getting worse. So that, we turned the strategy to sell the room package which will be valid for one year ahead, started from July, 1st 2020". (P7 - Sales Manager).

Moreover, the other strategy also implemented to boost the hotel revenue,

"We created the program "Palembang staycation Bae," which is a flash sale for Palembang market. By this program, we hit the bottom-line rates to grab the opportunity from FIT or Family". (P3 - General Manager).

Some hotels applied the flash sale as an attractive way to get the attention of the public which also applied to the local chain hotel,

"We launched the Best Deal Package 1 on April 2020. Then, we extend the Best Deal 2 from

May to August 2020. After that, we create the flash sale for stay period until June 2021". (P1 Corporate Revenue Director).

In the same vein, the hotel revenue manager from City Centre Hotel explained,

"When the city restriction is open, people who get bored to stay at home will find an accommodation to do refreshing near their area. That is one of the reasons we set the staycation strategy with the discount applied $40 \%$ since we have seen the opportunity on it". (P9 - Revenue Manager).

In addition, to subsidize the room packages, the hotel finds an alternative strategy from Food and Beverage Department to complete the whole process. Some hotels were implied them as the prominent roles to run their operations.

"Domestic market has a significant demand to order the food package. Outside catering were offering with special rates to escalate the hotel's revenue". (P7 - Sales Manager).

In addition, the other hotel manager describes,

"The only way we could do to get the revenue as soon as possible is shifting the culture. People used to go to the hotel and enjoy their food with the hotel ambiance. Meanwhile, we change the services to take-away and delivery services since restriction applied". (P6 - Corporate Revenue Director).

"The takeaway or delivery systems could support the basic hotel revenue since rooms have a low demand." (P5 - Corporate Revenue Director).

\subsection{The Crisis Response Stage}


The finding depicted that dealing with Covid-19, the hotel has activated and deployed its contingency plan and strategies. It is critical to communicate effectively during a crisis to diminish the misinterpretation and updating the hotel condition regularly. The hotel should establish excellent internal and external communication channels, so that hotel employees, guests, and the general public have access to up-todate crisis information (Fung et al., 2020). The success of a crisis management strategy must also be evaluated regularly. To ensure that crisis communication is successful, the organization should establish a crisis communication manager and pick a representative from all relevant organizational units as a member of the crisis communication team. (Fall \& Massey, 2006).

"We encourage our employee who has the other skill such as painting so that we could ask them to create a mask painting to sell to the public. Moreover, we collaborated with Local Micro, Small, and Medium Enterprises and held the virtual fashion show with a well-known local designer. Moreover, the Government held the health protocol video competition in a hotel to gain the customer trust to stay at the hotel during pandemics. By promoting these activities, we would like to inform the public, we still existed and survived" (P10 - Marketing Communication Manager).

\subsection{The Crisis Recovery Stage}

Following the disaster situation, the hotel must develop a recovery strategy and rebuild its facilities (Novelli et al., 2018). The crisis in the short run will unavoidably impact the hotel business. However, a welldesigned recovery plan and marketing strategy can turn the crisis into an opportunity in the long run. This stage provides the hotel with an opportunity to remedy the issue and re-establish its brand image. Some hotel managers have explained their marketing strategy for medic reservation in this stage as following descriptions.

"Since Government informed the Social Restriction or PSBB (Pembatasan Sosial Berskala Besar), there is an opportunity for a hotel to grab the market segmentation for company workers who want to conduct the rapid test which held at the hotel. Some of them need room packages and others, the meal packages". (P9 - Revenue Manager).

The Opportunity also came for new market segmentation for Health Activities,

"We provide the residential package for Public Health Department, Government, and any services related to the health recovery (Quarantine) and Vaccinations which included the laundry service with tight protocol applied" (P12 - Human Resources Manager).

For international guests, the hotel could have an opportunity for quarantine packages. Some of the hotel areas joined the hotel who recommended to be an accommodation after international travel. 
"The embassy will contact the recommendation hotel to provide the accommodation for their citizen for quarantine or vice versa (before they come back to their country)." (P4 - Director of Sales).

New packages have been offered to approach a company and are in line with government suggestions to support the hotel industry during the pandemic with this package.

"We sell the Work from Hotel Packages which include meals and strong connection with low rates offer." (P10 - Marketing Communication Manager).

The new way of MICE activity at the hotel also adjusted to the pandemic situation. For instance, the wedding receptions commonly held in face-to-face conditions recently shifted to virtual weddings due to restrictions.

"We provide the virtual wedding at our hotel and use the technology to publish the wedding to the guest who could not join due to limitation of guest invitation." (P-10 - Marketing Communication Manager).

\section{DISCUSSION}

Considering the hotel industry's four phases of crisis management practices during the pandemic, most marketing strategies are downgraded. In the initial stage, the strategy was compromised with cancellation and postponed booking to waiver action as a decision. Therefore, the hotel marketing and management should prepare the disaster plan strategy to overcome unpredictable movement. However, the second phase, where the hotel should have an instant strategy to cope with the issues, did the new tactics to increase sales. According to Kim et.et al.005), interestingly, at the end of the SARS crisis, many hotels in Korea provided cheap rooms and effectively increased occupancy rates to levels seen previous to the pandemic. Next, the organization should thoroughly assess its current crisis management methods and tactics (Fung et al., 2020). Subsequently, the crisis response stage is where the hotel is fully aware of new circumstances, which are steady to deal with by looking for any opportunities to survive, enhancing their creativity involving the stakeholders to maintain their brand image to the public. Due to the devastating impact of Covid-19, the hotel must establish and adapt the new market segmentation by grabbing the new account such as the health department or any group related to health, quarantine, and vaccine support to activate the hotel revenue keep the hotel operations running as a normal. Although marketing practices were not emphasized in the initial or pandemic stage, there was a trend in the recovery stage to emphasize marketing practices. Once the restricted regulations and travel ban are lifted, hotel marketers should develop promotional programs. The Hotel might even create and sell attractive rooms and beverages packages that include discount rates for future stays to boost cash flow and accelerate the post-crisis recovery. 


\section{CONCLUSION}

Through this study, we contribute to hotel management education by giving a real-world scenario and a set of practical suggestions for Hospitality Management to learn about crisis circumstances and more significantly, the strategy to survive during an outbreak. As a result, despite the more demanding and complex pandemic situation, the implications of this study provide essential direction for governmental intervention and marketing decisions for long-term economic growth in Hotel Industry.

The limitation of this study is mainly the scarce digital strategies exploration that can enhance the hotels' marketing strategy holistically. Particularly, marketing techniques to tackle the difficulties in the price war phenomenon and compete for tight business with decreasing market segmentation through the online travel agent or websites, and the factors influenced to reduce the actual rates during a pandemic.

Therefore, further study is recommended to explore the hotels' digital marketing strategy in the context of pandemic and also recovery stage to update the new strategy applied to complete the Crisis Management Framework. However, quantitative research needs to be conducted to get a comprehensive insight into how effective the hotel marketing strategy affects society to support Hospitality Business during the pandemic. Other studies on hotel crisis management have highlighted the significant impact on the Tourism Industry and urged that further research is needed to comprehend the various aspects of a pandemic crisis fully.

\section{ACKNOWLEDGEMENT}

This research was fully funded by the Research and Innovation Centre of Universitas Multimedia Nusantara, Indonesia. In addition, the authors would like to give a high appreciation for the hotel's director and managers who were involved in enlightening this study.

\section{REFERENCES}

Alexandra, Y. and Choirisa, S. F. (2021) 'Understanding college students' e-loyalty to online practicum courses in hospitality programmes during COVID-19 ", Journal of Learning Development in Higher Education. Plymouth, UK, (21). doi: 10.47408/jldhe.vi21.627.

Baum, T., Mooney, S. K. K., Robinson, R. N. S., \& Solnet, D. (2020). COVID-19's impact on the hospitality workforce - new crisis or amplification of the norm? International Journal of Contemporary Hospitality Management, ahead-of-print(ahead-of-print). doi:10.1108/ijchm-04-2020-0314

Burnett, J. (2002). Managing Business Crisis: From anticipation to implementation. Westport: Quorum

Cloudman, R., \& Hallahan, K. (2006). Crisis communication preparedness among US organizations: Activities and assessments by public relations practitioners. Public Relations Review, 32 (4): 367376. https://doi.org/10.1016/j.pubrev.2006.09.005 
Denzin, N. K., \& Lincoln, Y S. (1994). Introduction: Entering the field of qualitative research. In N. K. Denzin \& Y S. Lincoln (Eds.), Handbook of qualitative research. Thousand Oaks, CA: Sage

Enz, C. (2002). The best of times, the worst of times: Differences in hotel performance Following 9/11. The Cornell Hotel and Restaurant Administration Quarterly, 43(5): 41-52. doi:10.1016/s00108804(02)80055-6

Fall, L. T., \& Massey, J. E. (2006). The significance of crisis communication in the aftermath of 9/11: A national investigation of how tourism managers have re-tooled their promotional campaigns. Journal of Travel \& Tourism Marketing, 19(2-3): 77-90. https://doi.org/10.1300/J073v19n02_07

Fung, C. P., \& Hon, A. H. (2019). How to provide an optimal environment for tourists to manage their sleep? The roles of sleep amenities, sleep environment cleanliness and sleep atmosphere. Journal of Hospitality Management and Tourism, 10(2): 9-19.

Gillham, B. (2005), Research Interviewing: The Range of Techniques, McGraw-Hill Education, Berkshire. Hao, F., Xiao, Q., \& Chon, K. (2020). COVID-19 and China's Hotel Industry: Impacts, a Disaster Management Framework, and Post-Pandemic Agenda. International Journal of Hospitality Management, 102636. doi:10.1016/j.jijhm.2020.102636

Israeli, A. A., Mohsin, A., \& Kumar, B. (2011). Hospitality crisis management practices: The case of Indian luxury hotels. International Journal of Hospitality Management, 30(2): 367374. doi:10.1016/j.jhm.2010.06.009

Japutra, A., \& Situmorang, R. (2021). The repercussions and challenges of COVID-19 in the hotel industry: Potential strategies from a case study of Indonesia. International Journal of Hospitality Management, 95, 102890. doi:10.1016/j.jijm.2021.102890

Kim, S.S., Chun, H. and Lee, H. (2005), "The effects of SARS on the Korean hotel industry and measures to overcome the crisis: a case study of six Korean five-star hotels", Asia Pacific Journal of Tourism Research, 10(4): 369-377.

Lai, I. K. W., \& Wong, J. W. C. (2020). Comparing crisis management practices in the hotel industry between initial and pandemic stages of COVID-19. International Journal of Contemporary Hospitality Management, ahead-of-print(ahead-of-print). doi:10.1108/ijchm-04-2020-0325

Lai, I.K.W. and Wong, J.W.C. (2020), "Comparing crisis management practices in the hotel industry between initial and pandemic stages of COVID-19", International Journal of Contemporary Hospitality Management, 32(10): 3135-3156. https://doi.org/10.1108/IJCHM-04-2020-0325

Laws, E., \& Prideaux, B. R. (2017). A study of crisis management strategies of hotel managers in Washington. DC Metro Area. Tourism Crises: Management Responses and Theoretical Insight, 103118. https://doi.org/10.4324/ 9780203819821-12.

Lee, K. (2009). How the Hong Kong government lost the public trust in SARS: Insights for government communication in a health crisis. Public Relations Review, 35(1): 74 -76.

LI, S., CHEN, C., ZHANG, H., GUO, H., WANG, H., WANG, L., .. XIAO, P. (2005). Identification of natural compounds with antiviral activities against SARS-associated coronavirus. Antiviral Research, 67(1): 18-23. doi:10.1016/j.antiviral.2005.0

Liu, B., Pennington-Gray, L., \& Klemmer, L. (2015). Using social media in hotel crisis management: The case of bed bugs. Journal of Hospitality and Tourism Technology, 6(2): 102-112. https://doi.org/10.1108/JHTT-08-2014-0036

McKercher, B., \& Chon, K. (2004). The Over-Reaction to SARS and the Collapse of Asian Tourism. Annals of Tourism Research, 31(3): 716-719. doi:10.1016/j.annals.2003.11.0

Neuman, L. and Robson, K. (2009) Basics of Social Research: Qualitative and Quantitative Approaches. Pearson, Toronto. 
Neuman, W. L. \& Robson, K. (2014). Basics Of Social Research.Toronto: Pearson Canada.

Novelli, M., Burgess, L. G., Jones, A., \& Ritchie, B. W. (2018). 'No Ebola ... still doomed'-The Ebolainduced tourism crisis. Annals of Tourism Research, 70: 76-87. https://doi.org/10. 1016/j.annals.2018.03.006

Pacific Asia Travel Association (PATA). (2003). Crisis: It won't happen to us!, Retrieved on 20 June 2019 from https://www. pata.org/\#

Pacific Asia Travel Association (PATA). (2015). How to develop a risk management strategy for a tourism destination. Retrieved on 12 Feb 2020 from https://sustain.pata.org/wp-content/ uploads/2015/02/Destinations-Instructors-English.pdf

Pennington-Gray, L., Thapa, B., Kaplanidou, K., Cahyanto, I., \& McLaughlin, E. (2011). Crisis planning and preparedness in the United States tourism industry. Cornell Hospitality Quarterly, 52(3): 312-320. https://doi.org/10.1177/ 1938965511410866

Rai, N., \& Thapa, B. (2015). A study on purposive sampling method in research. Kathmandu: Kathmandu School of Law.

Rosenthal, U., Boin, A., \& Comfort, L. K. (Eds.) (2001). Managing crises: Threats, dilemmas, opportunities. Springfield, IL: Charles C. Thomas Publishers.

Sigala, M. (2020). Tourism and COVID-19: impacts and implications for advancing and resetting industry and research. Journal of Business Research. doi:10.1016/j.jbusres.2020.06.015

Silva, D. W. (2003). About SARS: The mystery pneumonia. Retrieved July 13, 2003, from http://www.abc.net.au/ science/features/sars/default.htm

Soemodinoto, A., Wong, P. P., \& Saleh, M. (2001). Effect of Prolonged Political Unrest on Tourism. Annals of Tourism Research, 28(4): 1056-1060. doi:10.1016/s0160-7383(01)00011-1

Suri, H. (2011), "Purposeful Sampling in Qualitative Research Synthesis", Qualitative Research Journal, 11(2): 63-75. https://doi.org/10.3316/QRJ1102063

Tew, P. J., Lu, Z., Tolomiczenko, G., \& Gellatly, J. (2008). SARS: Lessons in strategic planning for hoteliers and destination marketers. International Journal of Contemporary Hospitality Management, 20(3): 332-346. https://doi.org/10.1108/ 09596110810866145

Tracy, S. J. (2010). Qualitative Quality: Eight "Big-Tent" Criteria for Excellent Qualitative Research. Qualitative Inquiry, 16(10): 837-851. https://doi.org/10.1177/1077800410383121

Wan, Y. K. P. (2013). A comparison of the governance of tourism planning in the two special administrative regions (SARs) of China-Hong Kong and Macao. Tourism Management, 36, 164-177.

WHO (2020a), "Novel coronavirus (2019-nCoV) situation report - 1", available at: www.who.int/docs/default-source/coronaviruse/situation-reports/20200121-sitrep-1-2019ncov.pdf?sfvrsn=20a99c10_4

WHO (2020b), "Novel coronavirus (2019-nCoV) situation report - 11", available at: www.who.int/docs/default-source/coronaviruse/situation-reports/20200131-sitrep-11ncov.pdf?sfvrsn=de7c0f7_4

WHO (2020c), "WHO characterizes COVID-19 as a pandemic", available at: www.who.int/emergencies/diseases/novel-coronavirus-2019/events-as-they-happen 